\title{
アルミナの熱水反応における不純物の影響
}

\author{
小野修一郎*・山口悟 郎**・柳田博 明**・清 水 紀夫*** \\ (*,東京工業試験所, ** 東京大学, ***千葉工業大学)
}

\section{Effects of Impurities on Hydrothermal Reactions of Alumina}

By

\begin{abstract}
Shuitiro ONO*, Goro YAMAGUCHI**, Hiroaki YANAGIDA** and Tadao SHIMIZU***
(* The Government Chemical Industrial Research Institute, Tokyo, ** Department of Industrial Chemistry, Faculty of Engineering, University of Tokyo, *** Department of Industrial Chemistry, Chiba Institute of Technology)
\end{abstract}

Corundum $\left(\mathrm{Al}_{2} \mathrm{O}_{3}\right)$ was obtained from boehmite ( $\mathrm{AlOOH}$ ) under hydrothermal conditions at temperatures above $400^{\circ} \mathrm{C}$. The grain size of the crystals with definite habit was 10 to 100 microns.

In the present study impurity effects on the crystallization process of corundum in the above reaction have been investigated. It was found that the reaction rate, crystal size and habit, and incorporation of added ions were strongly influenced by temperature change, $\mathrm{pH}$ change, and addition of impurities into solution.

These observed data were explained as the results of impurity effects on: (1) solvent structure, (2) solution structure, (3) solubility, (4) diffusion process, (5) nucleation process, and (6) growth process.

In some cases a metastable phase was formed under the influence of certain impurity. Fluorine ion in the solution inhibited the corundum nucleation and caused the formation of tohdite in the corundum stable region. This effect was explained as a change of solution structure, that is, structure change of hydrated poly aluminate ion in the solution by the existence of fluorine ion. It must be noted that the solution structure is an important factor for the crystallization process.

Habit modification of corundum by adding iron group ions as sulfate, nitrate, chloride, hydroxide or oxide was determined. Valency and coordination number of these ions incorporated into the corundum lattice were determined from their visible reflection spectra. Copper ion is not solid soluble in corundum if sulfate ion coexists, while it is solid soluble substitutionally as $\mathrm{Cu}^{3+}$ in 6 coordinated site if it is added as nitrate, oxide or hydroxide. Judging from the formation mechanism of "Star" corundum, Copper ion seems not to be incorporated into the lattice through the basal plane (0001). [Received Oct. 13, 1967]

\section{1. まえがき}

水晶の熱水合成以来，熱水反応は，工業化学的見地氻 ら各種の有用な単結晶合成手段として, 鉣物学的には天 然鉱物の成因を探る手段として，多くの研究者によって 取り上げられてきた。アルミナー水系の熱水反応は，レ 一ザー用ルビー単結晶を合成する有力な手段の一つとし て近年特に注目されているにもかかわらず，その反応機 構に関する研究が比較的少ないのは, 反応が密封された 高圧ボンベの中で行われるので，直接追跡することが困 難なことによるのであろう．特に巨大な容器を使って行 う単結晶合成は実験が大変で, 基礎的な反応機構の研究 をするには不便である，そこで我々は内容 $10 \mathrm{cc}$ 程度の 小さいオートクレーブを使って熱水条件下での粉末試料 の相変化の反応を研究し, 反応におよぼす不純物効果を 調べた。
アルミナの熱水反応を論ずるためには，アルミナー水 系の正しい状態図が必要で，これについては多くの研究

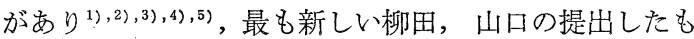
のを図-1 に示す5 ${ }^{5}$. 確認された安定相は, ダイアスポア $\left(\mathrm{Al}_{2} \mathrm{O}_{3} \cdot \mathrm{H}_{2} \mathrm{O}\right.$ または $\left.\mathrm{AlOOH}\right)$ とコランダム $\left(\mathrm{Al}_{2} \mathrm{O}_{3}\right)$ だ けであり, $370^{\circ} \mathrm{C}$ 以下に現われるべーマイト $\left(\mathrm{Al}_{2} \mathrm{O}_{3} \cdot \mathrm{H}_{2} \mathrm{O}\right.$ または $\mathrm{AlOOH})$ は準安定相である. Torkar と Krischner ${ }^{4)}$ はアルカリを完全に除いた系ではジブサイト $\left(\mathrm{Al}_{2} \mathrm{O}_{3} \cdot 3 \mathrm{H}_{2} \mathrm{O}\right.$ または $\left.\mathrm{Al}(\mathrm{OH})_{3}\right)$ 生成域でバイヤライト $\left(\mathrm{Al}_{2} \mathrm{O}_{3} \cdot 3 \mathrm{H}_{2} \mathrm{O}\right.$ または $\left.\mathrm{Al}(\mathrm{OH})_{3}\right)$ が生成することを確为 ているので，ジブサイトはアルカリの存在下で生成する 準安定相とも考えられる.コランダム安定領域でトーダ 1卜 $\left.\left.\left(5 \mathrm{Al}_{2} \mathrm{O}_{3} \cdot \mathrm{H}_{2} \mathrm{O}\right)^{6)}, 7\right), 8\right)$ が生成するのは，特定の不純 物を添加した場合のみであり，準安定相である.

ここでは主に図-1の (7)と(9)の反応における微量不純 


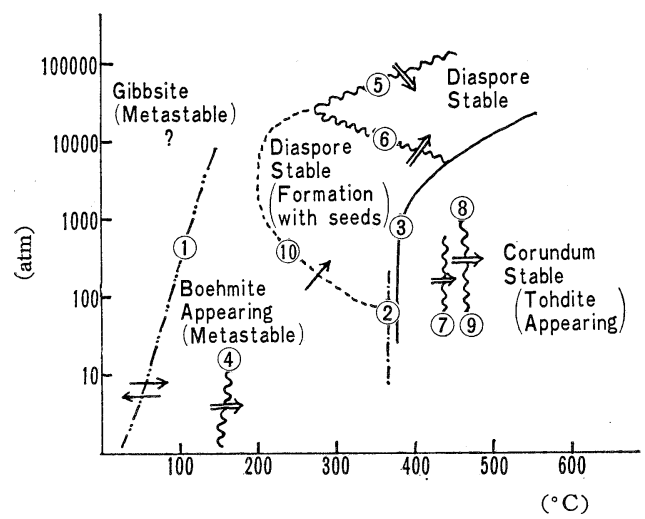

$\longrightarrow$ : transformation with use of seed crystals of the more stable phase

$\Rightarrow$ : spontaneous transformation without seeds within 60 hrs

- : equilibrium curve between two stable phases

.... : equilibrium curve between a stable phase and a metastable phase

-..-.. : equilibrium curve between two metastable forms

.... : initiation curve for transformation with seeds

: initiation curve for transformation without seeds

(1) Gibbsite $\rightleftarrows$ Boehmite, (2) Boehmite $\rightleftarrows$ Corundum

(3) Diaspore $\rightleftarrows$ Corundum, (4) Gibbsite $\Rightarrow$ Boehmite

(5) Gibbsite $\Rightarrow$ Diaspore, (6) Boehmite $\Rightarrow$ Diaspore

(7) Boehmite $\Rightarrow$ Corundum (8) Diaspore $\Rightarrow$ Corundum

(9) Boehmite $\Rightarrow$ Tohdite (10) Boehmite $\rightarrow$ Diaspore

Fig. 1. A revised diagram of the system $\mathrm{Al}_{2} \mathrm{O}_{3}-\mathrm{H}_{2} \mathrm{O}^{5}$.

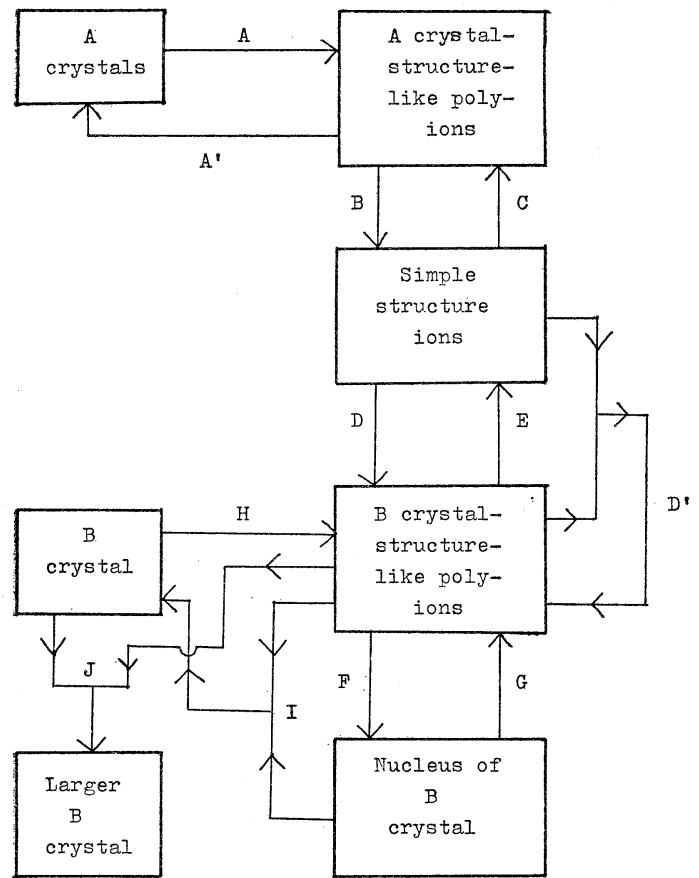

Fig. 2. The reaction scheme for $\mathrm{B}$ phase formation from another phase of $A^{5)}$.

物効果を取り扱う。純粋系での，(1)ジブサイトのベーマ イト化 ${ }^{9)}$, (7)ベーマイトのコランダム化反応 ${ }^{10)}$ とついて は山口, 柳田らの研究があり, 図-2 に示すような反応 機構を提出している. 熱水反応の特異性は, 過臨界状態
の水を溶媒として用いることにあるが，このような状態 で水の性質がどんな変化を受けるか必ずしも明らかでな い. 水に不溶性の物質がこの状態の水に対してかなりの 溶解度を示すことが多く, 従って熱水反応が成立する訳 である.つまり熱水反応は一種の溶解析出反応であり, 溶液からの結晶析出に準じた取り扱いができる.図-2 は その溶解析出結晶生成の過程を表わしたものである.

溶液からの結晶化におよぼす不純物の影響は, 次章に 述べるように反応の各過程における不純物効果に分けて 考え, かつそれらの間の相関性を把握することによって 完全に理解できると考えられる. 残念ながらアルミナの 熱水反応については, 前に述べたような実験上の難点が あって, 決して所期の目的にかなった成果が得られた訳 ではないが，一応概括的な理解は得られたと考兄られる ので,ここに論文としてまとめることにした. 以下午長 なデータの羅列を避けるために, 興味ある結果だけを適 当に挙げながら不純物効果について考察していく.

\section{2. 微量不純物の結晶化におよぼす影響}

\section{1 溶媒との相互作用}

まず考えなければならないことは，溶媒中に存在する 不純物イオンと溶媒との相互作用である.最も良い例が， 不純物を添加することによって $\mathrm{pH}$ が変化する場合であ る. その他にも不純物イオンの存在が溶媒構造に影響す ることは充分考えられる. 熱水条件下の水の構造を直接 測定する方法はないが, 例えば, 純水中に八ロゲンイオ ンが溶けると, 水の複合イオンの結合を切ることや ${ }^{11)}$, その他水の構造に影響することが知られている ${ }^{12)}$.この ような溶媒構造の変化が直接, 間接に反応におよぼす影 響を無視することはできないだろう，不純物の影響を調 べる時に注意しなければならない点は，不純物を添加す ると $\mathrm{pH}$ の変化を伴ならことが多く, 本来の不純物の影 響と $\mathrm{pH}$ による影響とが分離しにくいことである。

図-3,4 はベーマイトのコランダム化反応に㧍ける $\mathrm{pH}$

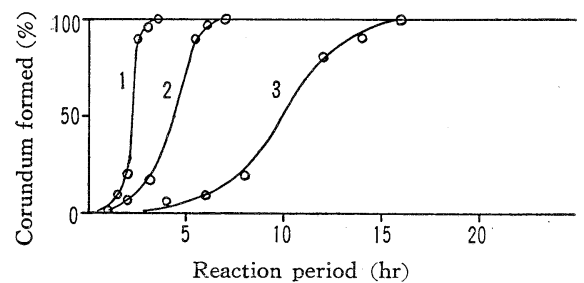

$1: 0.1 \mathrm{~N} \mathrm{NaOH}, 2:$ pure water, $3: 0.1 \mathrm{~N} \mathrm{H}_{2} \mathrm{SO}_{4}$.

Fig. 3. The reaction rate of corundum formation at $450^{\circ} \mathrm{C}$ and $1000 \mathrm{~atm}$.

(a)

(b)

(c)

(d)
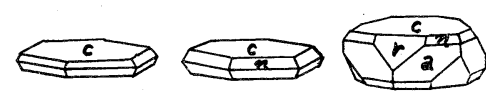

$(n, c)$

$(n, c, a, r)$

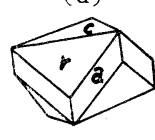

Higher $\mathrm{pH} \leftrightarrow$ Lower $\mathrm{pH}$

Fig. 4. pH effect on crystal habit of corundum. 
の効果を, 反応速度, 生成コランダムの晶癖, 粒径につ いて示したものである. 反応速度曲線は, ベーマイトを 所定時間熱水反応させた後とり出して乾燥し, $900^{\circ} \mathrm{C}$ 以 上に加熱した時の脱水減量から反応率を計算して, 時間 に対してプロットしたものである.詳しくは文献 ${ }^{10)}$ 照されたい. 溶液の $\mathrm{pH}$ 值は反応容器に入れる前の值で ある. 反応速度酒酸性になるほど小さくなり, 晶癖はア ルカリ側で $c$ 面 (0001), $n$ 面 (112̄3) から成る六角板状, 酸性になると $r$ 面 $(01 \overline{1} 2)$ の発達が顕著になり $c$ 軸方向 にもっと成長した粒状を呈する．粒子の大きさは酸性側 の方が大である.このような $\mathrm{pH}$ の効果は後で溶解度, 成長機構に関連して考察する.

\section{2 溶質構造との相互作用}

溶質構造 と溶媒構造とを合せて, 以下溶液構造 と呼 ぶ、溶液中で溶質イオンがどのような形で存在している かを直接測定することは困難であるが，溶液構造は溶液 反応において極めて重要である. 常圧下での水溶液中の アルミニウムイオンの構造は赤外，ラマン吸収などの手 段を用いてある程度知ることができる ${ }^{13)}$. Fripiat らの 赤外吸収の解析では, $\mathrm{Al}_{4}(\mathrm{OH})_{8}{ }^{4+}, \mathrm{Al}_{6}(\mathrm{OH})_{15}{ }^{3+}$ のよう な複合イオンの形で溶けていると考えられている到。 Carreira らは，アルミン酸イオンの構造が $\mathrm{pH}$ によっ て変化することを赤外，ラマンスペクトルによる対称性 加推定した ${ }^{13)}$ 。熱水条件下では，大きさは違っている かもしれないが，ともかくこんな形の複合イオンが存在 している訳であり, もし溶液の $\mathrm{pH}$ が変ったり, 異種イ オンが存在したりすれば，複合イオンの結合が切れて大 きさが変化したり，異種イオンと結合して形が変ったり することが考えられる。

このような溶液構造の変化は, 溶質イオンの溶解度, 溶解速度, 拡散速度, 核生成の難易などに影響をおよぼ すことになる。

\section{3 溶解度, 溶解速度}

まず溶解度の意味を明確にしておこう。ある溶媒中に 西る溶質が溶け得る限界の量, すなわちそれ以上溶ける と熱力学的に固相として分相する方が安定になる量を溶 解度と定義している. 従ってこれは液相に対して定義さ れる量であって，溶質イオンが同じならいっも一定の溶 解度を示すことになる. しかし我々の扱うのは普通, 固 相 (結晶) と液相 (溶液) の共存状態であって, この場 合結晶相の溶解量を決的るものは, 結晶表面と溶液との 間の平衡関係であると考える方が実際的であるう．ここ でいう溶解度とはこのような意味での溶解度である. 従 って溶解度は結晶相の表面状態に依存するはずであり，

粉末状態の固相の溶解度が粒子の大きさによって違った り, 単結晶の溶解度が溶液と接している結晶面の種類に よって違うことになる。

さて溶液中に添加された不純物イオンが溶解度, 溶解
速度に与える影響を考えてみると，

(1)まず先程の溶液構造の変化を通して溶解度, 溶解速 度に影響するはずである。

(2) 次に不純物イオンが結晶表面に吸着することによ り, 面と溶液との間の平衡関係を乱し, 溶解度, 溶解速 度が減少することが考えられる. 例えば Gallily と Friedlander $\mathrm{LiF}$ 単結晶の水に対する溶解速度が溶液 中に $\mathrm{Fe}$ イオンが存在すると著しく遅くなることを確か め，それを吸着不純物イオンによる溶解度の減少による と説明した ${ }^{15)}$.

こうして生じた溶解度の変化は次の反応過程にその影 響をおよぼしていく。

(1) ${ }^{\prime}$ 核生成速度は溶液中の溶質濃度と生成相の溶解度 との差, つまり過飽和度に極めて強く影響される。

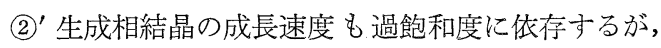
その程度は核生成に比べて小さい.

(3) 生成相の結晶粒の大きさは, 核生成と成長の相対 的速度に依存している.つまり（成長速度/核生成速度） の值が大きくなれば, 結晶粒も大きくなる. 一般に過飽 和度が小さくなると, 成長速度よりも核生成速度の減少 が著しく, 生成結晶粒は大きくなる.

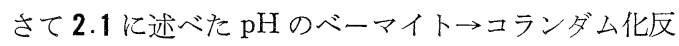
态に対する効果を検討してみよう・コランダムの熱水条 件下に扔ける溶解度は溶液中の $\mathrm{OH}$ イオンの量に比例す ることが実験的に確かめられており ${ }^{16)}$ ，アルカリ側では かなり大きく(図 -5 参照), 純水から酸性側では測定でき ないほど弱い。ベーマイトの溶解度は $400^{\circ} \mathrm{C}$ 以上では直 接測定できないが，同じような傾向を示すと考えてよい ので, 両者の溶解度差, つまり過飽和度に相当する值は 酸性側で小さくなり, 従って反応速度は減少し, 粒子の 大きさは大きくなるはずである。図-3 の反応速度曲線 は確かに酸性側で遅くなり, 生成粒の粒径はほとんど変 らないが， $c$ 軸方向に厚みができて大きさは増してい る. もし不純物添加の効果がこれと同じ傾向を示す場合 には，不純物によって生じた $\mathrm{pH}$ の変化によるものと考

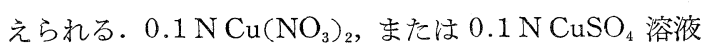
( $\mathrm{pH} 3$ 程度) 中でのコランダム生成反応は, 純水中に 比べて著しく遅く, 生成コランダム粒子はむしろ小さく なる。これはこれらの塩の影響は $\mathrm{pH}$ 值による溶解度の 減少だけでは説明できないことを示している.

次に弗素イオンの効果について述べる. 溶液中に弗素 イオンがある濃度以上存在すると, ベーマイトのコラン ダム化は完全に停止し, 別の準安定相トーダイトが生成 する ${ }^{8)}$ ここの効果を調べるために，弗素イオン存在下の コランダム溶解度, 溶解速度を求めた。 図 -5 は $2 \mathrm{~N}$ $\mathrm{NaOH}$ 溶液中およびそれに $\mathrm{NaF}$ を添加した場合につい てのコランダム溶解曲線を示している. 溶解量は溶液中 の $\mathrm{NaOH} 1 \mathrm{~g}$ 当量に対するアルミナの $\mathrm{g}$ 当量数で表わ 


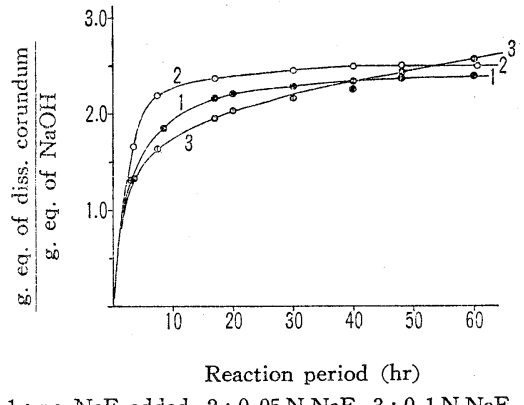

$1:$ no $\mathrm{NaF}$ added, $2: 0.05 \mathrm{~N} \mathrm{NaF}, 3: 0.1 \mathrm{~N} \mathrm{NaF}$.

Fig. 5. Dissolution curves of corundum in $2 \mathrm{~N} \mathrm{NaOH}$ aqueous solution at $460^{\circ} \mathrm{C}, 1000 \mathrm{~atm}$.

している. 実験に使ったコランダムは 1 粒子当り平均重 量 $0.40 \mathrm{mg}$ の純度 $99 \%$ 以上の電融コランダムで,これを 一定量精密に秤量し, 所定温度で所定時間熱水処理した 後急冷しメッシュと傾泻法によって沈殿物を洗い流し た残りのコランダム粒子の重量を秤って，その減量から 溶解度を求好た.詳しくは他の文献 ${ }^{16)}$ を参照されたい.図 からわかる通り, 飽和溶解度洂费素イオン濃度が増加す るにつれて増しているけれども, 溶解速度については 2 つの傾向が見られる。 $0.05 \mathrm{~N} \mathrm{NaF}$ 濃度では溶解速度が 増大しているのに対して，0.1 N NaF 濃度ではむしろ 減少している. 高濃度で起る溶解速度の減少は, (2)の弗 素イオンのコランダム表面への吸着による影響と考えて よい，弗素イオンの表面吸着は当然溶解度も減少させる はずであるが, 実験結果は逆に弗素イオン濃度の増加に 対応して溶解度も増大している.これは(1)溶漼構造に よる効果と考えられる.つまり 2.2 亿述べたようなアル ミニウム複合イオンの中に弗素イオンが結びついて, 複 合イオンの形や大きさに変化を与え，その結果コランダ ムの溶解度が増加すると予想される. 弗素イオン効果に 関するデータをもら少し挙げると， $2 \mathrm{~N}-\mathrm{NaOH}$ 水溶液 中 $0.5 \mathrm{~g}$ 当量 $/ l$ 以上の弗素イオンがあると, コランダム 核生成が妨げられてトーダイトが生成するが，この濃度 でもコランダム種子があれば，その成長は阻害されな $\left(^{8}\right.$. $0.1 \mathrm{~N} \mathrm{NaF}$ 以上の濃度でのコランダム溶解度は測 定していないが，2 $\mathrm{N} \mathrm{NaOH}$ 溶液中より多少大きいと考 えて溶液中のアルミナ濃度を推定し，弗素イオン $0.5 \mathrm{~g}$ 当量 $/ l$ 濃度での溶液中の $\mathrm{Al}$ と $\mathrm{F}$ の数の比を計算する と，およそ $3: 1$ 程度になる。この位の比率で $\mathrm{Al}$ と $\mathrm{F}$ を 含む複合イオンが溶液中に形成される時，コランダム核 の生成が困難になるのであろう。ささに弗素イオン濃度 が大きくなるにつれて，コランダムの溶解度が大きくな り, 従って安定性が減少することも，トーダイト生成の 一因になるかもしれない，準安定相トーダイト生成に掠 ける不純物效果については別報で詳しく述べるつもりで ある。

\section{4 成長面へのイオンの拡散速度}

我ふの実験ではあまり重要な問題にならないが，ある
種の固-液反応では，イオンの拡散速度が律速になるこ とがよくある。この場合は，不純物イオンが拡散速度に およぼす影響を考える必要がある.例えば，

(1)溶液構造の変化によるもの. 不純物や $\mathrm{pH}$ の変化に よって溶液中の複合イオンの形や大きさが変わることが あれば，大きなイオンは拡散しにくくなるような現象が 起る ${ }^{17)}$.

(2)一般に異種イオンの存在は拡散を妨げることが認め られている ${ }^{17)}$.

(3)場合によっては，不䋨物イオンの成長面への拡散が 成長速度を律速することも考えられる，例えば，成長速 度を低下させている吸着不純物が，面の厚化に伴って格 子中に包み込まれて表面から除かれる場合，不純物は絶 えず周囲から結晶表面へ拡散してくることになる。不純 物イオンの拡散が遅ければ，成長速度の低下が小さいこ とになる ${ }^{18)}$.

拡散律速の反応で，このような不純物効果がある場合 には，その影響は，

(1)'成長速度に拈いて最を著しく，

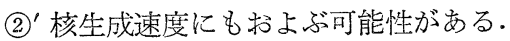

\section{5 核 生 成}

溶液からの核生成理論については，ここでは触れない が，臨界核（critical nucleus）について簡単に説明す る. 溶液中の複合イオンが重合して生成相の構造をとり ながら，次第に安定な成長核になる過程において，生成 核の表面エネルギーを energy barrier と考えると,小さ い核は表面エネルギーが大きく効いてくるため, エネル ギー的に不安定で再び溶解してしまう，そしてある大き さ以上に達した核のみが安定な成長核として制くことに なり，この限界の大きさを臨界核で表わしている.

従って，溶液中の不継物イオンが核生成におよぼす影 響は次のように要約される.

(1)溶解度の変化を通して．例えば，pH の影響に関し て既に述べたように。

(2)核の表面に不純物イオンが付着することによって表 面エネルギーに変化をおよぼす場合，その影響は当然核 生成におよぶ。

(3)溶液構造の変化を通して，弗素イオンのコランダム 核生成を妨げる作用が，アルミニウム複合イオンの変化 によることをすでに説明した。

(4)不溶性異物が存在する場合，それが preexisting center として核生成を容易にすることがある．図-6 に 示すように, $0.1 \mathrm{~N}-\mathrm{NaOH}$ 水溶液中に $\mathrm{Zn}$ 粉末を加光 ると，加えない時より反応速度が早くなるのはこの例で あろう。この場合の生成コランダム結晶の表面は異物の 付着によるキズがついている． $\mathrm{CuO}$ 添加の実験でも同 様の例がみられた。

(5)不純物の一種として考えられるものに種子結晶の添 


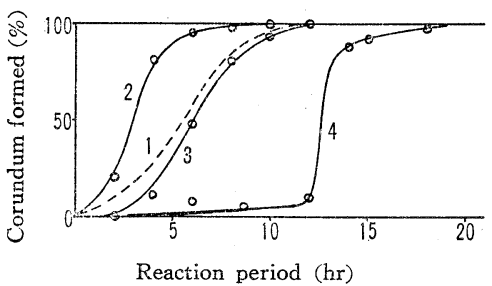

$1: 0.1 \mathrm{~N} \mathrm{NaOH}$

$2: 0.05$ mole $/ l Z$ n powder $-0.1 \mathrm{~N} \mathrm{NaOH}$

$3: 0.005 \mathrm{M} \mathrm{K}_{2} \mathrm{CrO}_{4}-0.1 \mathrm{~N} \mathrm{NaOH}$

$4: 0.05 \mathrm{M} \mathrm{Na}_{2} \mathrm{~B}_{4} \mathrm{O}_{7}-0.1 \mathrm{~N} \mathrm{NaOH}$.

Fig. 6. The reaction rate of corundum formation from gibbsite at $440^{\circ} \mathrm{C}$ and 1000 atm. $0.1 \mathrm{~g}$ corundum seed added.

加がある. 生成相の結晶を少量添加することによって核 生成が著しく容易になることは，一般的に認められてい る. ベーマイトのコランダム化反応の種子効果は山口， 柳田によって研究され，その機構を次のように説明して いる5 . 図-2 に示した反応図において，ベーマイトをA 相，コランダムをB相とした場合, B crystal を種子とし て添加すると，溶解過程Hによってある程度 B crystal の構造を保った複合イオン， B crystal-structure-like poly-ions が生じ，これが A crystals が溶けて生成し た Simple structure ions を $\mathrm{D}^{\prime}$ 過程によって $\mathrm{B}$ crystalstructure-like poly-ions に導く役目をする。 そのため に Nucleus of B crystal が生成し易くなると推定され る. ベーマイトのトーダイト化においても，トーダイト の種子効果が 認められることは表-1 の結果から明らか である.面白いことには，コランダム種子を添加しても やはりトーダイト核生成が促進される (Expt. 3).もっ

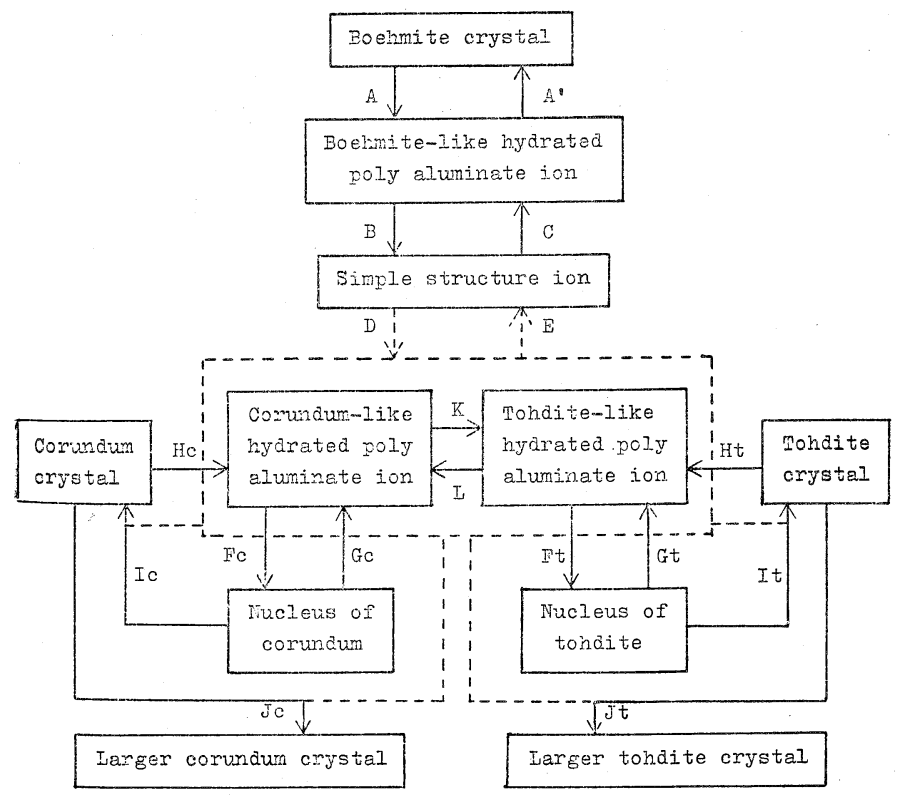

Fig. 7. The reaction scheme for the transformation of boehmite into corundum or tohdite in the presence of fluorine ion.
Table 1. Hydrothermal reaction of boehmite in the presence of fluorine (water density $0.6 \mathrm{~g} / \mathrm{m} l$ )

Expt. Temp. Time Conc. of $\mathrm{F}$ Seed Product

\begin{tabular}{ccccc}
$\left({ }^{\circ} \mathrm{C}\right)$ & $(\mathrm{hr})$ & $\begin{array}{c}\text { ion } \\
\text { (g. eq. } / l)\end{array}$ & $\begin{array}{c}(\mathrm{mg}) \\
\text { without seed }\end{array}$ & Boeh \\
450 & 40 & 0.55 & Toh. 50 & Toh. \\
450 & 40 & 0.55 & Cor. 50 & Toh. \\
450 & 40 & 0.55 & without seed & Toh. + Boeh \\
450 & 40 & 0.25 & Toh. 50 & Toh. \\
450 & 40 & 0.25 & Cor. 50 & Toh. + Cor. \\
450 & 40 & 0.25 & \multicolumn{5}{c}{ Corundum) }
\end{tabular}

とも弗素イオン濃度の低い場合は，コランダム種子は当 然コランダム核生成を促進している (Expt. 6).このコ ランダム種子効果は図-7 のように説明される。ベー マイトが溶解して生じた Simple aluminate ions が Corundum-like hydrated poly aluminate ion Tohdite-like hydrated poly aluminate ion になる重合 過程Dが起りにくいので反応が進まない，そこへコラン ダム種子を加えると，溶解して Corundum-like poly ion を生成する (過程 Hc)，これは弗素イオン漲度の高 い条件下では Tohdite-like poly ion になってしまう (過程 $\mathrm{K}$ )。その結果 Simple aluminate ion は過程 D, Ft を通ってトーダイトを生成することになる．過程 K, Lの転移には弗素イオン濃度によってきまる平衡状態が あり，低濃度では Corundum-like poly ion が相対的に 増えて，一部または全部コランダムが生成することにな る.このような複合イオン構造の変化を先程は, 溶液構 造の変化として説明したのである.弗素イオンがどんな 風にして溶液構造を変化させるかについては，別報で詳 しく説明する.

そのほかに，核生成が著しく妨げられる 例として図-6の $\mathrm{Na}_{2} \mathrm{~B}_{4} \mathrm{O}_{7}$ の影響がある。 誘導時間が長く，一度反応が始まると急速 に反応してしまうことは，核生成が起りに くく成長速度は早いことを意味する。生成 するコランダムは，図-8 に示すように特 徵的な樽状の晶癖を示し，単結晶とはい元 ないほど久陷の多い粒子である。このこと は粉末 X 線回折線が非常に broad になる ことからもわかる，興味深いことは，ボ口 ンもトーダイト生成の鉣化刻として非常に 有効であることである ${ }^{199}$. そのほか， $\mathrm{Ti}\left(\mathrm{SO}_{4}\right)_{2}, \mathrm{CuSO}_{4}$ なども添加量が多いと， ベーマイトの一部または全部がトーダイト に転移する。しかもこれらの不純物は, 微 量でもコランダム核生成を強く阻害する点 で共通している。この事寒から予想される ことは，“準安定相トーダイトは鉱化剤の 存在によって安定化されるのではなく, こ れらの鉣化剂によって安定相コランダムの 


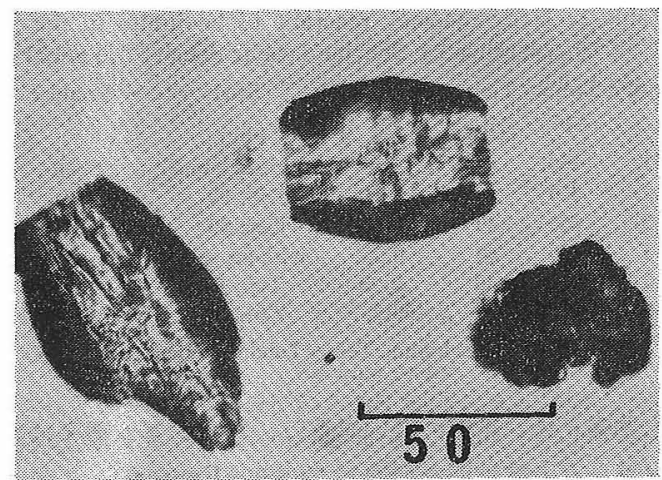

Fig. 8. Crystals of corundum formed in the solution of $0.05 \mathrm{M} \mathrm{Na}_{2} \mathrm{~B}_{4} \mathrm{O}_{7}$ and $0.1 \mathrm{~N} \mathrm{NaOH}$.

核生成が妨げられる結果出現する”といらことである。 よく準安定相が不純物によって安定化されるという表現 が使われるが，その中には上のような場合が多いと思わ れる。

このような核生成速度の変化は,

(1) 成長速度との相対的関係によって, 生成結晶の大 きさを左右し，

(2) ささらに重要なことは，上に述べたように，準安定 相の出現に決定的な影響を与えることである.

\section{6 結晶成長}

溶液からの結晶成長理論について簡単に説明する。 ず理想的な結晶面の成長は，成長面上での二次元稯生成 によって律速される、そして核生成の場合と同様に，“二 次元嵒界核”に相当寸る高いポランシャル状態を経るた めに，活性化エネルギーはかなり高い。これに対して準理 想的な成長機構として, “Dislocation Theory”がある。 これは screw dislocation を成長源と考える理論で, 二 次元核生成を必要としないため，活性化エルギーは比較 的小さい.

不純物が成長におよぼす影響は次の原因による・?

(1)溶液構造の変化

(2)溶解度，溶解速度の変化

(3)拡散律速の反応では，抾散速度の変化

(4)不綎物の結晶面への吸着による成長茦度の減少。従 って，各結晶面の二次元的構造が問題になる.

(5)結晶内に包含された不䋖物久陷によって起る成長速 度の増大.

そしてその結果は，

(1) 粒子の大きさ

(2) 各結晶面の相対的成長速度より，その晶癖

(3) 余り成長速度が大きい場合には, 生成結晶の欠陥 を多くすること，

などに現われてくる．逆に我くはこれらの現象を通し て，成長に肪よぼす不純物効果に関する知見を得る訳で ある。

まず各結晶面の成長の活性化エネルギーについて検討
してみよう．反応温度による生成コランダムの晶癖変化 は図-4 に示した $\mathrm{pH}$ による変化とよく似ている ${ }^{20)}$ 。す なわち高温側で $c$ 面の発達した (a) 型，低温になると $c$ 軸方向にもっと成長した $r, a$ 面主体の (c), (d) 型にな る.このことから各面成長の活性化エネルギーについて 次の相対的関係が予想される。

$$
r>n, a \gg c
$$

Kuznetsov の単結晶䏍成実験からの結果では ${ }^{21)}$, $r(32 \mathrm{kcal} / \mathrm{mol})>n>a(17.5 \mathrm{kcal} / \mathrm{mol}) \gg c$

でよく一致する.面によって成長の活性化エネルギーが 極端に異なるのは，成長機構の相違に基づくと考光られ る. $c$ 面の活性化エネルギーが他の面に比べて非常に小 さい事実は，この面の成長が二次元核生成のような高い ポテンシャル状態を必要としない，つまり常に面上に kink の位置が充分ある荒れた面の成長であることを示 している. 事実生成コランダムの $c$ 面はあまり滑らかで ない。それに郝して $r$ 面， $n$ 面はいつも滑らかで，活性 化エネルギーの大きいこと考考えると，その成長機構は 二次元核生成によるものと考えられる，勿論これは不絉 物が存在しない場合の話である。こういら風に考える と，実は $\mathrm{pH}$ による晶癖変化がうまく説明される，前に 述べたように $\mathrm{pH}$ が下がると過飽和度が下がる。それに よる影響は各面によって，特に成長機構の相違によって 異なるはずである，r面のように二次元核生成を必要と する面の成長は $c$ 面のように活性化状態党必要としない 場合に比べて，過飽和度の減少の影響を強く受けるはず である. その結果は， $c$ 朝方向に厚みのある $r$ 面の発達 した晶癖を生ずることになる。

多数の不純物について調べた結果，不純物を添加した 場合の生成コランダムの晶癖は, $r$ 面の発達するのがも っとも一般的で, 次に $n$ 面， $a$ 面であり， $c$ 面を発達さ せることはほとんどない200)。これは二次元核生成のよう な高いエネルギーの活性化状態を必要とする面ほど，不 純物イオンの妨害を受け易いこと宗している.

唯一の例外は弗素イオンの効果である.この場合, 生 成コランダムは図-9 に示すように $c$ 面の非常に発達し

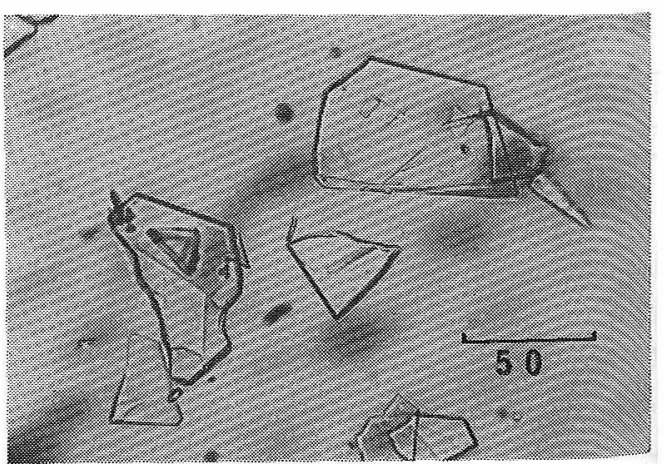

Fig. 9. Crystals of corundum formed in the presence of fluorine ion. 
た薄板状である．弗素イオン濃度を濃くするとトーダイ トが得られるが，これも全く同じような薄板状結晶で見

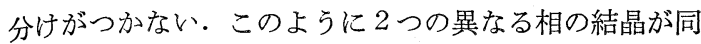
じ不純物イオンによって同じ影響を受けることは興味深 、. 何故なら，これは $c$ 面への弗素イオンの吸着による と思われ, 乙かも両相の $c$ 面の二次元構造は酸素の密充 填層におおおわれてる点で共通している。

ほかに特徵的な成長速度を示す例として, ボロンが挙 げられる，すでに述べたように，成長は著しく早く，特 徵的な晶癖を示す. ボロンは普通アルミニウムと同じ原 子価 3 をもち，この限りでは固溶し易いはずである.し かし $\mathrm{B}^{3+}$ のイオン半径は $0.2 \AA$ で, $\mathrm{Al}^{3+}$ の $0.5 \AA$ に 比べて小さく ${ }^{22)}, \mathrm{B}^{3+}$ の安定な酸素配位は面内 3 配位構 造である. $\mathrm{B}^{3+}$ は抢そらくコランダム格子中 $\mathrm{Al}^{3+}$ の 6 配位位置に置換固溶していると考えられるけれども，こ のようなイオン半径の違いが格子中に欠陷を生じ易いこ とは充分考えられる，その結果(5)の効果によって成長が 早くなるであるう。そして早い成長はさらに久陷の生成 を助長し, 図-6 のような特徵ある反応曲線 が 得られる ことになる。

次に $\mathrm{SO}_{4}{ }^{2-}, \mathrm{NO}_{3}{ }^{-}$などの陰イオンの影響に触れてお く.これらのイオンの存在が反応速度に何らかの影響を 与えることは図-10を見れば理解できる. 反応曲線は核 生成速度と成長速度が重なった結果であるから, 特徵的 な場合を除いて別々に論ずることはむずかしいが，これ らのイオンが反応を遅くしていることは確かである．溶 液は強いアルカリ性で $\mathrm{pH}$ の影響は無視してよい，ただ 硫酸根, 硝酸根の影響が弗素イオンやボロンなどと異な る点は, 晶癖に変化を与えないことである.図-4の (d) のような $0.1 \mathrm{~N}-\mathrm{H}_{2} \mathrm{SO}_{4}$ 溶液中の生成コランダムの晶癖 は $\mathrm{pH}$ の影響として理解できるし, 実際 $0.1 \mathrm{~N}-\mathrm{HNO}_{3}$ ! 溶液中でも晶癖, 粒径とも同じ結果が得られる.

不純物が成長におよぼす影響は全体的影響と選択的影 響の 2 つた別して考えることもできる．前者は晶癖に 変化を与えないもので(2)どは典型的な例であろう．後 者は晶癖変化の原因となるような影響で，特殊な場合を 除いて結晶面への不純物の吸着によると考えてよい，従 って上に挙げた陰イオンの効果が吸着によるものではな

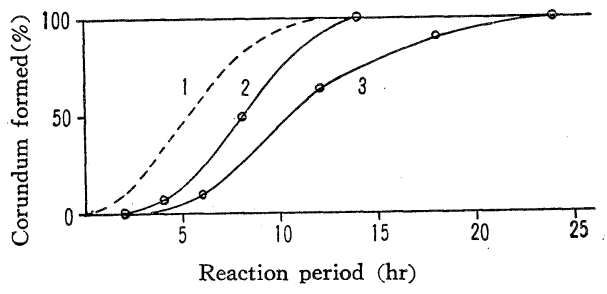

$1: 0.1 \mathrm{~N} \mathrm{NaOH}, 2: 0.01 \mathrm{~N} \mathrm{Na}_{2} \mathrm{SO}_{4}-0.1 \mathrm{~N} \mathrm{NaOH}$, $3: 0.01 \mathrm{~N} \mathrm{NaNO}_{3}-0.1 \mathrm{~N} \mathrm{NaOH}$.

Fig. 10. The reaction rate of corundum formation at $440^{\circ} \mathrm{C}$ and $1000 \mathrm{~atm} .0 .1 \mathrm{~g}$ corundum seed added.
くて, 溶液構造に基づくものらしいことが予想される。

\section{3. 不純物イオンの固溶}

水熱合成による不純物固溶の着色コランダムについて は前報で報告したが ${ }^{20)}$ ，それらの粉末試料の可視部の 反射スペクトルを図-11, 12 に示した. $\mathrm{Cu}\left(\mathrm{NO}_{3}\right)_{2}$ 添加

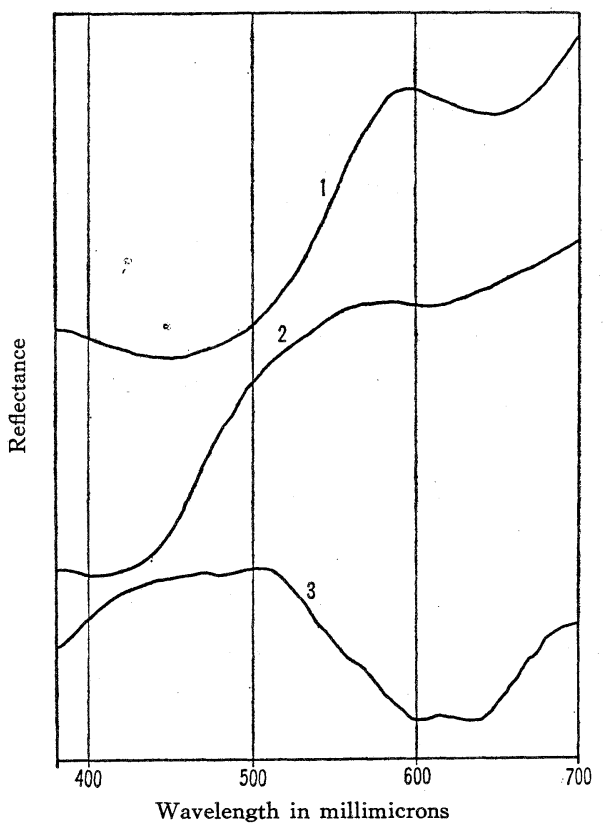

Fig. 11. Visible reflectance spectra of some metallic ion doped corundums prepared in ; $1: 0.1 \mathrm{M}$ $\mathrm{Cu}\left(\mathrm{NO}_{3}\right)_{2}, 2: 0.1 \mathrm{M} \mathrm{Ni}\left(\mathrm{NO}_{3}\right)_{2}, 3: 0.1 \mathrm{M} \mathrm{NiSO}_{4}$.

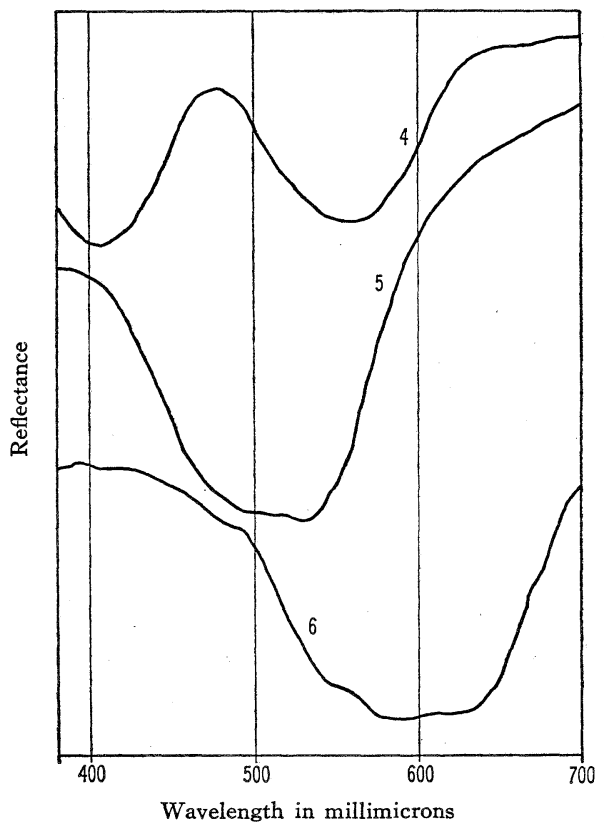

Fig. 12. Visible reflectance spectra of some metallic ion doped corundums prepared in $; 4: 0.025 \mathrm{M}$ $\mathrm{K}_{2} \mathrm{CrO}_{4}, 5: 0.1 \mathrm{M} \mathrm{Mn} \mathrm{SO}_{4}, 6: 0.1 \mathrm{M} \mathrm{CoSO}_{4}$. 
による茶色のコランダム（Cu 0.60 wt％）の吸収は， Geschwind らがコランダム単結晶中の 銅イオンについ て ESR の結果から 6 配位 3 洒と決定したものの吸収と 一致するので ${ }^{23)}{ }^{24)}$ ，固溶銅イオンは 6 配位 3 価である. $\mathrm{Ni}\left(\mathrm{NO}_{3}\right)_{2}$ 添加による黄色 (Ni.0.67 wt\%), $\mathrm{MnSO}_{4}$ 添 加による赤色 $(\mathrm{Mn} 0.31 \mathrm{wt} \%), \mathrm{K}_{2} \mathrm{CrO}_{4}$ による赤色 (Cr0.3wt\%) は, McClure の測定したスペクトル ${ }^{25)}$ と比較してすべて 6 配位 3 価である. $\mathrm{NiSO}_{4}$ による青色 (Ni 0.38wt\%) は Müller と Günthard ${ }^{26)}$ の得た吸収ス ペクトルとの一致から 6 配位 2 価と決定してよい.この 青色は空気中 $900^{\circ} \mathrm{C}$ で加熱すると, $\mathrm{Ni}^{3+}$ の黄色に変わ ることでも 2 価であることがわかる。これらのイオンは すべて $\mathrm{Al}^{3+}$ に置換固溶していると考えてよい.上に挙 げた固溶量は, 粉末試料を重硫酸カリ融液中で表面をと かして完全に付着物を除いた後，比色分析によって得た 值である. 図-12 @ $\mathrm{CoSO}_{4}, \mathrm{CoCl}_{2}$ 添加による青色は, 重硫酸カリ中で表面をとかすと消えてしまらので固溶コ バルトイオンの色ではなく同時に生成した $\mathrm{CoOAl}_{2} \mathrm{O}_{3}$ スピネルの色と思われる.この吸収スペクトルは 4 配位 2 価のコバルトイオンのものである ${ }^{26), 27) .}$

表- 2 は $\mathrm{Cu}$ と $\mathrm{Ni}$ の硫酸塩, 硝酸塩の 0.1 モル水溶 液中で $800 \mathrm{~atm}$ 下，種々の温度でベーマイトをコラン ダム化したときの生成コランダム中の $\mathrm{Cu}, \mathrm{Ni}$ の固溶量 である. 温度によって固溶量はかなり違うが，それより も興味をひくのは, 陰イオンの種類によって全く様子が 変ってくることである. $\mathrm{Cu}\left(\mathrm{NO}_{3}\right)_{2}$ では銅イオンは 3 価

Table 2. Colorimetric Analyses of Hydrothermal Corundums

(a) Copper (weight\%)

$\begin{array}{llll} & 440^{\circ} \mathrm{C} & 450^{\circ} \mathrm{C} & 460^{\circ} \mathrm{C} \\ \mathrm{Cu}\left(\mathrm{NO}_{3}\right)_{2} & 0.55 & 0.60 & 0.24 \\ \mathrm{CuSO}_{4} & & 0.06 & 0.01\end{array}$

(b) Nickel (weight \%)

$\begin{array}{lclc} & 450^{\circ} \mathrm{C} & 460^{\circ} \mathrm{C} & 500^{\circ} \mathrm{C} \\ \mathrm{Ni}\left(\mathrm{NO}_{3}\right)_{2} & 0.61 & 0.67 & 0.27 \\ \mathrm{NiSO}_{4} & 0.38 & & \end{array}$

で置換固溶し， $r$ 面の発達した晶癖をもつ茶色コランダ ムになる、ところが $\mathrm{CuSO}_{4}$ の形で添加すると, 生成コ ランダムは $n$ 面の発達した晶癖をもつ無色の結晶で, 比 色分析の結果は銅はほとんぞ固溶しないことがわかる。 ニッケルの場合も, $\mathrm{Ni}\left(\mathrm{NO}_{3}\right)_{2}$ では $\mathrm{Ni}^{3+}$ 置換固溶の黄 色コランダムで $r$ 面の発達した形, $\mathrm{NiSO}_{4}$ では $\mathrm{Ni}^{2+}$ 置 換固溶の青色コランダムで $r$ 面の発達した形と, 塩の種 類による違いが著しい，晶癖と固溶との関係は後で述べ るとして, 表-3 は銅, ニッケル, コバルト, マンガン を硫酸塩, 硝酸塩, 塩化物, 水酸化物, 酸化物の形で添 加した際の固溶金属イオンの原子価をまとめたものであ る. no と記したのは固溶しない意味で, Coイオンでは 実際にコランダム中には固溶しないが，スピネルを生成 して2 価になっているという意味で $\mathrm{Co}^{2+}$ とした. 一般 的傾向として, $\mathrm{SO}_{4}{ }^{2-}, \mathrm{Cl}^{-}$が共存すると金属イオンは低
Table 3. Valency of iron group ions incorporated into the corundum lattice when they are added as sulfate, nitrate, chloride, hydroxide or oxide.

$\begin{array}{cccccc}\text { Added cation } & \mathrm{SO}_{4}{ }^{2-} & \mathrm{NO}_{3}- & \mathrm{Cl}^{-} & \mathrm{OH}^{-} & \mathrm{O}^{2-} \\ \mathrm{Cu}^{+} & * & * & \mathrm{no} & * & \mathrm{Cu}^{3+} \\ \mathrm{Cu}^{2+} & \mathrm{no} & \mathrm{Cu}^{3+} & \mathrm{no} & \mathrm{Cu}^{3+} & \mathrm{Cu}^{3+} \\ \mathrm{Ni}^{2+} & \mathrm{Ni}^{2+} & \mathrm{Ni}^{3+} & \mathrm{Ni}^{2+} & \mathrm{Ni}^{2+} & \mathrm{Ni}^{2+} \\ \mathrm{Ni}^{3+} & * & * & * & * & \mathrm{Ni}^{3+} \\ \mathrm{Co}^{2+} & \mathrm{Co}^{2+} & { }^{2+} & \mathrm{Co}^{2+} & \mathrm{Co}^{2+} & * \\ \mathrm{Mn}^{2+} & \mathrm{Mn}^{3+} & \mathrm{Mn}^{3+} & \mathrm{Mn}^{3+} & * & * \\ \mathrm{Mn}^{4+} & * & * & * & * & \mathrm{Mn}^{3+}\end{array}$

原子価になるのに対して, $\mathrm{NO}_{3}{ }^{-}$は少し変っており，高 い原子価になるようである. 硝酸根が特に酸化雾囲気を 与えるためと思われる．また共通して金属イオンは 3 価 で固溶し易いことがわかる． $\mathrm{Ni}^{2+}$ も固溶するけれども $\mathrm{Ni}^{3+}$ に比べて固溶量も少なく，固溶しにくいことが経 験的にわかっている. $\mathrm{Co}^{2+}$ も固溶しない，以上挙げた ほかに固溶していると思われるものは， $\mathrm{NaBiO}_{3}$ 添加に よるビスマスと $\mathrm{NH}_{4} \mathrm{VO}_{3}$ 添加によるバナジウムがある が，両方共 3 価の原子価をもち，アルミニウムに置換固 溶すると考えてよい．またボロンも 3 価で置換固溶する ようである。

結晶成長過程に扔いて異種イオンが格子中に固溶し易 いかどらかを決めるには，次の点を考慮しなければなら ない。

(1)異種イオンの原子洒, イオン半径と母結晶イオンの それらとの関係. 安定配位数の問題.

（2溶液中での異種イオンの形．原子価や溶液構造が問 題になる.

(3) 結晶面の面構造.

著者らの実験結果では，金属イオンがアルミニウムと同 じ 3 価で置換固溶する場合がほとんぞで，イオン半径に ついては, $\mathrm{Al}^{3+}$ の 0.5 に対して $\mathrm{B}^{3+}$ の 0.20 から $\mathrm{Bi}^{3+}$ の 1.20 までばらついている. つまり原子価の一致が最 も重要とされる訳である.この理由は charge compensationのためであろう． 3 価の置換固溶の場合はこの必 要はないが，例えば $\mathrm{Ni}^{2+}$ が $\mathrm{Al}^{3+}$ と置換固溶するため には，電荷のバランスを保つために，付近に $\mathrm{H}^{+}$が侵入 固溶するなどの必要が生ずる ${ }^{26)}$.

結晶面との関連性は次の晶癖のところで触れる.

\section{4. 晶癖}

温度, 圧力による晶癖の変化, $\mathrm{pH}$ による晶癖変化に ついては既に述べた。一般には純水中で生成するコラン ダムの晶癖は図- 4 の (b) の上らな $c$ 面と $n$ 面からなる六 角板状である. 熱水中に不純物イオンが存在すると，図 -13 に示すようないろいろな晶癖をもつコランダムが得 られる. あらゆる晶癖変化を通じて現われる結晶面は,

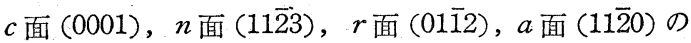
4 つのみである. 4 つの面がすべて現われた場合は図 -4 


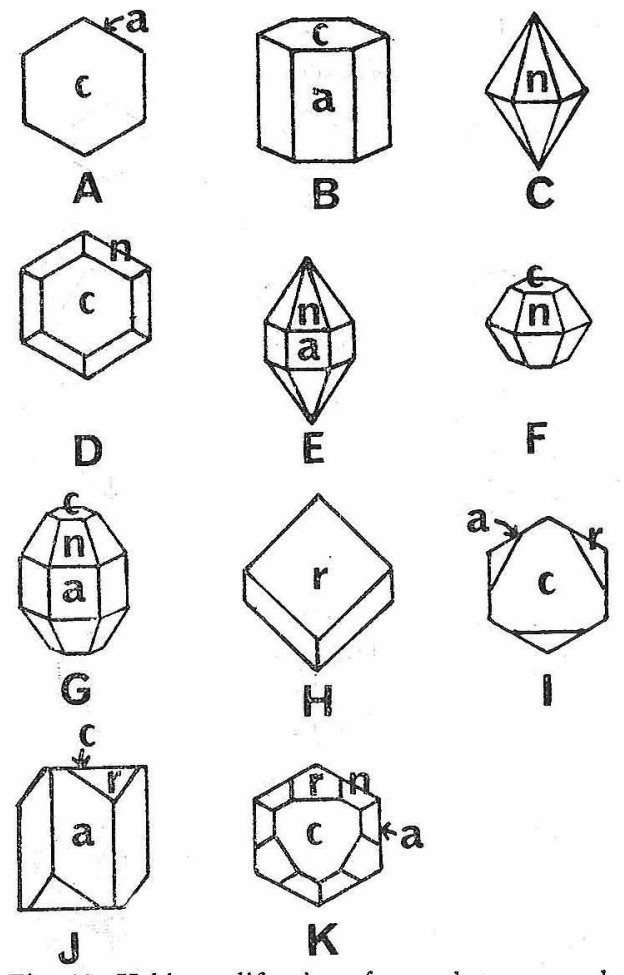

Fig. 13. Habit modification of corundum prepared hydrothermally from boehmite.

の (c) である。

不純物を添加した時の形状の变化は，大別して次の 3 つの傾向に分類される.すなわち $n, c$ 面より成る [D] 型の板状を基準にして，

(1) $r$ 面が発達する。 $[\mathrm{H}][\mathrm{I}][\mathrm{K}]$ 型.

(2) $n$ 面が発達する. [C] $[\mathrm{E}][\mathrm{F}][\mathrm{G}]$ 型.

(3) $a$ 面 $c$ 面阮発達する. [A] [B] [ J ] 型.

$0.1 \mathrm{M} \mathrm{Cu}\left(\mathrm{NO}_{3}\right)_{2}$ 溶液中で得られた着色コランダム は，[H]または [I]型で(1)の傾向を示し， $r$ 面主体で ある.(以後 $r$ 型といら)。ただし着色の濃淡によって粒 子の形状に差違が見られ，濃く着色した粒子は $r$ 型であ るが，淡くしか着色していない粒子は， $n, c$ 面主体の形 状を示す (以後 $n$ 型とい5)。 $\mathrm{CuO}, \mathrm{Cu}_{2} \mathrm{O}$ などを添加し た場合の茶色コランダムもやはり $r$ 型である. $\mathrm{CuSO}_{4}$ 溶 液中で生成するコランダムは $[\mathrm{C}],[\mathrm{F}]$ などのn面の発 達した $n$ 型の晶癖を示し，銅イオンは固溶しない。とこ ろが $\mathrm{CuSO}_{4}$ 溶液中でも反心温度が $480^{\circ} \mathrm{C}$ 以上になる と，一部着色した結晶が生成し $r$ 型になる。結局銅イオ ンに関しては， $\mathrm{Cu}^{3+}$ で国溶する場合は $r$ 型，固溶しな い場合沙 $n$ 型といえる。

その他 (1) の傾向劣示す不純物法, $\mathrm{NiSO}_{4}, \mathrm{NiCl}_{2}$ ， $\mathrm{MnSO}_{4}, \mathrm{Zn}, \mathrm{CaCl}_{2}, \mathrm{CoSO}_{4}, \mathrm{CoCl}_{2}$ など多い. (2)の傾向 示不純物は, $\mathrm{Th}\left(\mathrm{NO}_{3}\right)_{2}$ (黄橙色着色), $\mathrm{Pb}\left(\mathrm{NO}_{3}\right)_{2}$ ， $\mathrm{ZnSO}_{4}, \mathrm{FeSO}_{4}$ などであるが, $\mathrm{ZnSO}_{4}, \mathrm{FeSO}_{4}$ では $a$ 面 の発達が著しく、 $\mathrm{Fe} イ$ イオ固溶は認められない。
(1)と(2)が大体一般的な傾向であるが，そのほかに特徴 的な晶癖を示す場合が(3)である。例えば, $\mathrm{NaBiO}_{3}$ を添 加すると， $a, c, r$ 面加らる $[\mathrm{J}]$ 型の柱状晶が生成す る.しかも茶系色に着色した非常に整った結晶である. また $0.025 \mathrm{M} \mathrm{Na}_{2} \mathrm{~B}_{4} \mathrm{O}_{7}$ 溶液中でっくったコランダムは, $a, c$ 面からなる [B] 型六角柱状晶である. 添加量が増 すと，わずかずつ方位のすれた微結晶の集合体のような 様相を示す. \&5一つ特暴な例は弗素イオン添加による $c$ 面の極めて発達した薄板状コランダム(図-9) であ る.どらも理由がよくわからないけれども，弗素もボロ ンも $\mathrm{NaBiO}_{3}$ も共通してトーダイト生成の鉱化剂とし て有効である ${ }^{19}$ 。しかもこれらの添加物がュランダムに 与える特徵的な゚晶瘁は，トーダイトを生成する場合にも 与えられることがわかった。これは雨者の緸造的類似性 に基づくものであろら. 弗素イオン效果に関して述べた ように，トーダイト生成の要因は，弗素イオンと水和重 合アル゚ン酸イオンとの結合による。このように水和重 合アルミン酸イオンと結びつき易いイオンは当然結晶面 とも結合し易いと思われる。そして結晶面に化学吸着し た不純物イオンは強く晶癖への影響をおよぼすことにな るであろら。

弗素イオンが $c$ 面の成長を押えるとすれば，他の八口 ゲンむ少しは似た傾向を示すかといらとそうでむない， 例えば， $\mathrm{AlCl}_{3}$ を多量に加えると眓-14のように $c$ 軸方 向に伸びた棒状のコランダムが生成した。

しかし遷移金属イオンの效果についてはある程度規則 性が認められる。まずはっきり云えることは，生成コラ ンダムの晶癖は 2 つ傾向に分けることができ，それは 金属イオンの固溶の有無と関連をもっていることであ

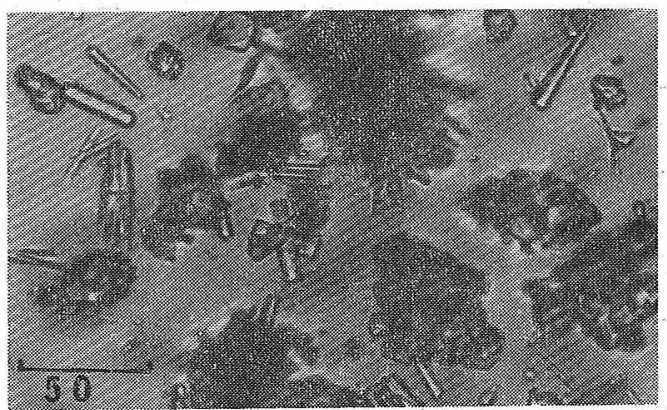

Fig. 14. Crystals of corundum formed when $\mathrm{AlCl}_{3}$ was added.

る.銅,ニッケル，マンガンなどが圊溶する場合は $r$ 面 の発達が著しく，これらのイオンの吸着が $r$ 面の成長を 押えることがわかる。 $\mathrm{CuSO}_{4}, \mathrm{FeSO}_{4}$ などのように金属 イオンが固溶しない場合は $n$ 型の晶癖を，才なわち $n$ 面 の成長を押える。

次に銅イオンの効果について少し詳細に検討してみよ 5. $0.1 \mathrm{M} \mathrm{CuSO}_{4}, 0.1 \mathrm{M} \mathrm{Cu}\left(\mathrm{NO}_{3}\right)_{2}$ 溶液中のコランダ 厶生成における不純物效果は $\mathrm{pH}$ に起因する溶解度の減 


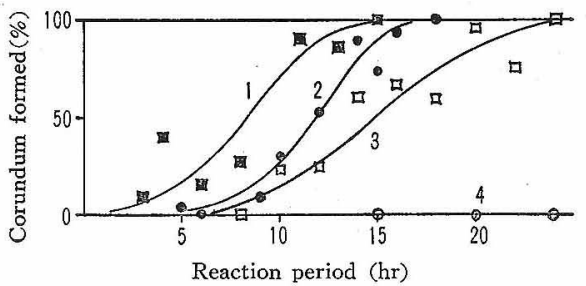

1: $470^{\circ} \mathrm{C}, 0.1 \mathrm{M} \mathrm{Cu}\left(\mathrm{NO}_{3}\right)_{2}, 2: 470^{\circ} \mathrm{C}, 0.1 \mathrm{M} \mathrm{CuSO}_{4}$,

$3: 450^{\circ} \mathrm{C}, 0.1 \mathrm{M} \mathrm{Cu}\left(\mathrm{NO}_{3}\right)_{2}, 4: 450^{\circ} \mathrm{C}, 0.1 \mathrm{M} \mathrm{CuSO}_{4}$.

Fig. 15. The reaction rate of corundum formation at $1000 \mathrm{~atm}$.

少や $\mathrm{NO}_{3}{ }^{-}, \mathrm{SO}_{4}{ }^{2-}$ イオンの影響なども考えられるけれ ども，それだけでは生成コランダムの特徴的な $n$ 型や $r$ 型の晶癖，著しい反応速度の減少（図-15)，および小さ な粒径を説明することはできない，したがって銅イオン の吸着が重要な原因になっていると考えられる。 $\mathrm{CuSO}_{4}$ の場合 2 洒と思われる $\mathrm{Cu}$ イオンは $n$ 面に強く吸着し, しかも $n$ 面から固溶しないので， step の前進を妨害す る效果は最も強いはずである. 事実反応速度が遅く， しかも生成粒の大きさが小さいことが確かめられた。 $\mathrm{Cu}\left(\mathrm{NO}_{3}\right)_{2}$ では, $\mathrm{Cu}$ イオンは $r$ 面に吸着し, その成長 を奶げるが，容易に固溶してしまうために，その効果は $\mathrm{CuSO}_{4}$ の場合の $n$ 面ほどではないといえる。このよう に吸着イオンの成長を妨げる効果は固溶しない場合の方 が固溶する場合より強いことは一般的にいえる。

次に $\mathrm{Cu}\left(\mathrm{NO}_{3}\right)_{2}$ 添加の実験で時々観察される生成コラ ンダムの写真を図-16に示す.これは着色粒子の中のた またま $c$ 面のよく発達した大きな結晶にみられるもの で，茶色の結晶の内部に無色の $r$ 型の結晶が含有されて いる。以後これを“スター”と呼ぶことにする。これは 無色のコランダムの上に着色コランダムが成長した訳で あるが，その成長に一風変っているところがある。ス夕

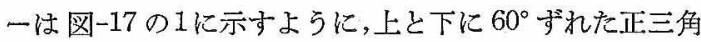
形の $c$ 面をもつ $r$ 型の無色コランダムであるが，ざ上 に着色コランダムが成長していく際， $c$ 面の上には着色 しないので正三角形の無色の部分が $c$ 面まで着色結晶を 貫いて出ている. 図-16 の (a) は上側の $c$ 面に焦点を合 せた写真で $c$ 面に三角形の無色の部分のあることがよく わかる．（b）はスターの中心に焦点が合わせてあり $r$ 面 のスターの上と下の $c$ 面がはっきりわかる。この結晶粒 の大きさは大体 $120 \mu$ である. スターの大きさは一定で

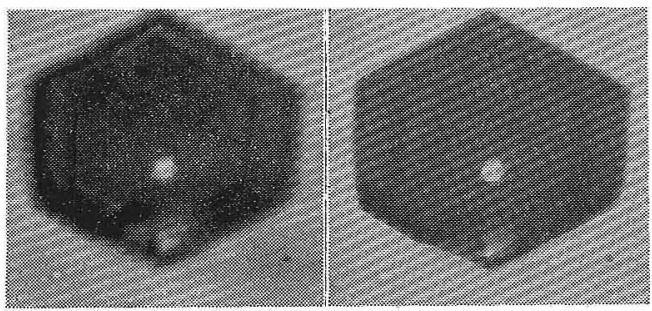

Fig. 16. Star corundum obtained from boehmite in $0.1 \mathrm{M} \mathrm{Cu}\left(\mathrm{NO}_{3}\right)_{2}$ solution.

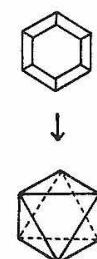

Nucleation

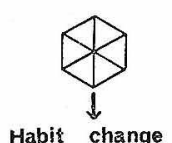<smiles>C1CCCCC1</smiles>

$\downarrow$
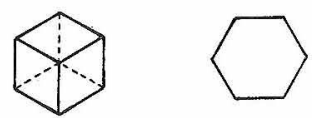

Growth

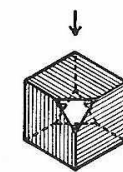

$\downarrow$
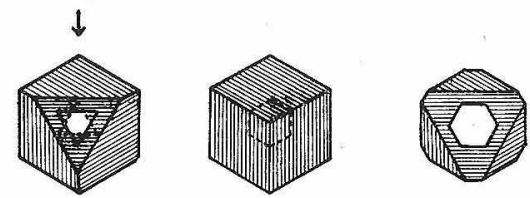

Habit change
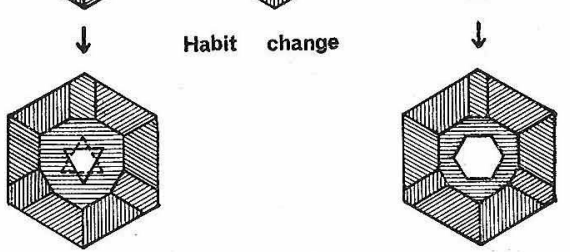

Fig. 17. Process of "Star" formation.

はなく, 数 $\mu$ ののから数十 ず $c$ 軸方向に無色の部分が $c$ 面から $c$ 面まで貫いてい る.もし $c$ 面が全くないか，または非常に小さいスター がこのような経過を経るとすると，スターは着色した $r$ 面でお掠われてしまい，はっきり無色の部分を見分ける ことはむずかしいが，そのような粒子の写真むある。ス ターが写真のようにはっきり観察される例はあまり多く ないが，ほとんどの粒子が中心部で着色が薄く，これに 近い過程を経て成長するものと考えられる.このスタ一 生成は銅イオンの影響について興味ある情報を与えてく れるけれども，完全に説明することはなかなかむずかし い.いろいる検討してみたが，生成の過程を実際に観察 できないため推論に過ぎないけれども，以下にもっとも 妥当と考光られる説明宗示々う。

スター生成の過程を図で表わしたのが図-17である。 図についてその生成過程を説明する。

(1)まず核ができる．この時銅イオンは固溶しにくく， 無色の $n$ 型の結晶としてある程度まで成長する。これは 散見される小さい無色の粒子功 $n$ 型であることから明ら かである。

(2)銅イオンの $r$ 面吸着による晶癖変化を経て $r$ 型にな る.これがスターである。この際， $c$ 面の発達の程度に よって図-17 の1,2,3のように様子が異なってくる. 3 は極端に $c$ 面が発達した薄板状の場合, 2 は $c$ 面のな 場合である。3の場合のスターは図-18 に示してある。 


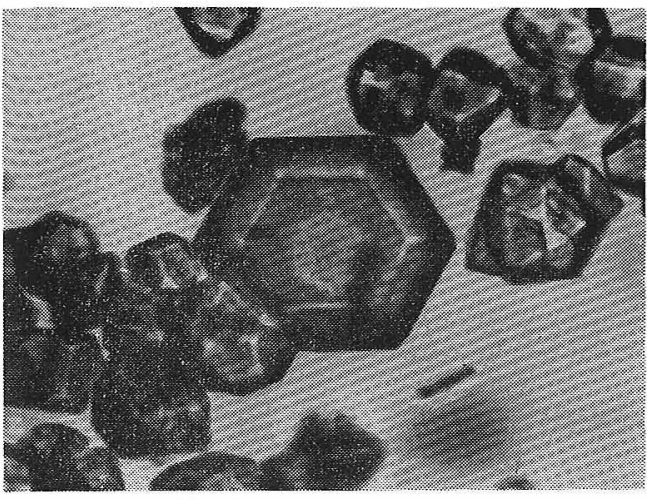

Fig. 18. Star corundum.

(3)スターは銅イオンを固溶しながら成長するが，スタ 一の $c$ 面を底面とする角柱の部分だけは銅イオンが固溶 せず， $c$ 軸方向に茶色結晶を貫いて無色の部分がはっき り区別される.2の場合は $c$ 面がないので $r$ 面でおおお れてしまう。

(4) 2 回目の晶癖変化が起り， $n$ 面が再び現われる。が その成長は銅イオンの固溶を伴なう点で初期の $n$ 型と異 なる。

(1)と(2)の過程は今までに述べた結果を重ゔけるもので あって問題はないが， $c$ 面の成長は奇妙である. 重硫酸 カリ融液中でエッチングして， $c$ 面のエッチピットを調 ベると，スターの中にのみエッチピットが現われること がわかる.このことは $c$ 面の成長中心がこの部分にある ことを示している. その成長中心から周囲へ step が前 進していく際，始めは銅イオンを固溶せず，三角形の部 分から外側では急に銅イオンが固溶するといらことはど らも考えにくい.したがって銅イオンは $c$ 面からは固溶 しないと伋定しておいて， $c$ 面の着色部分はす心てて $r$ 面 または $n$ 面の成長によって発達した部分であると考え る.つまりスターの $c$ 面はその大きさを保ったまま銅イ オンを固溶しないで成長を続け，その閒 $r$ 面はその $c$ 面 の成長に引張られて成長する。ある面の成長が稜を通っ て隣りの面の成長を促がすことは考えられることであ る. その後 $c$ 面の成長は止まるか，相対的に遅くなり， $r$ 面または $n$ 面の成長によって $c$ 面が発達していくた め, ととの三角形の外側には銅イオンの固溶した着色部 分が生ずることになる.このように考えると， $c$ 面のあ る結晶粒子のみが特に大きく成長すること, 角柱状の無 色の部分ができることは理解される.

(4)の $n$ 面が再び現われる理由は，次のように考えられ る. $r$ 面の晶癖は $n$ 面の成長が $r$ 面より早いために生ず ると考えてよい. 現実に $n$ 面が存在しないのに成長が早 いとか遅いとかいうのは和かしいらであるが，むし 面の成長が遅ければ， $r$ 面と $r$ 面の閒の稜の成長が押壳 られて $n$ 面が現われるはずである。前に述べたように。 $r, n$ 面は平坦な面で二次元核生成律速の成長と考えよ
5.ある結晶面上に二次元核の生成する確率は，その面 の大きさに比例するはずである，したがって結晶が成長 して $r$ 面が大きくなるにつれて成長速度は比例して大き くなるはずである，その結果 $r$ 面と $n$ 面の成長速度の相 違は小さくなり $n$ 面む現われる可能性がある.

以上の推論が正しいかどうかはさておいても，結晶が 成長において何度も晶癖変化をすること, 各面の成脣速 度も決して終始一貫一定ではないことなど，不純物效果 は決して一筋なわではいかないようである。

このように不純物イオンは結晶面に効して強い選択的 な効果を示すが，その固溶が格子久陷を増大し，極めて 早い成長をするときには，選択性が失われる傾向にな る・ボロンの踼合，まだはっきりした晶㾕ではあるが， 樽状の晶癖などはその例であろう。

\section{5.あと がき}

アルミナの熱水反応における不純物の影響を全般的に 論じたつもりである。著者らの考えでは，もっと単純な 系を用いて上に述べたような思想を基礎にした組織的な 研究を行ならことが望ましい訳である。そのためには溶 液構造の測定，表面自由エネルギーの導入，拉散速度な ど困難な問題がある。

\section{文献}

1) A.W. Laubengayer, R.S. Weisz, J. Am. Chem. Soc. 65, 247 (1943).

2) G. Ervin, E.F. Osborn, J. Geol. 59, 381 (1951).

3) G.C. Kennedy, Am. J. Sci. 257, 563 (1959).

4) K. Torkar, H. Krischner, Ber. Dtsch. Keram. Ges. 39, 131 (1962).

5) H. Yanagida, G. Yamaguchi, J. Ceram. Assoc. Japan 74, 36 (1962).

6) G. Yamaguchi, H. Yanagida, S. Ono, Bull. Chem. Soc. Japan 37, 752 (1964).

7) G. Yamaguchi, H. Yanagida, S. Ono, Bull. Chem. Soc. Japan 37, 1555 (1964).

8) G. Yamaguchi, H. Yanagida, S. Ono, J. Ceram. Assoc. Japan 74, 26 (1966).

9) 山口, 柳田, 工化, 66, 770 (1963).

10) G. Yamaguchi, H. Yanagida, Bull. Chem. Soc. Japan 38, 55 (1965).

11) W.R. Busing, F. Hornig, J. Phys. Chem. 65, 284 (1961).

12) J. Greyson, J. Phys. Chem. 71, 2210 (1967).

13) L.A. Carreira, V.A. Maroni, T.W. Swaine, Jr., R.C. Plumb, J. Chem. Phys. 45, 2216 (1966).

14) J.J. Fripiat, F. Van Cauwelaert, H. Bosmans, $J$. Phys. Chem. 69, 2458 (1965).

15) I. Gallily, S.K. Friedlander, J. Chem. Phys. 42, 1503 (1965).

16) G. Yamaguchi, H. Yanagida, S. Soejima, Bull. Chem. Soc. Japan 35, 1789 (1964).

17) V.N. Portnov, A.V. Belynstein, Soviet Phys.-Cryst. 10, 291 (1965).

18) G.D. Botsaris, E.A. Mason, R.C. Reid, J. Chem. Phys. 45, 1893 (1966).

19）投稿予定

20）山口, 柳田, 小野, 穼協, 71, 182 (1963).

21) V.A. Kuznetsov, Soviet Phys.-Cryst. 10, 561 (1966).

22）日本化学会編, 化学便覧 
23) W.E. Blumberg, J. Eisinger, S. Geschwind, Phys. Rev. 130, 900 (1963).

24) S. Geschwind, J.P. Remeika, Suppl. Appl. Phys. 33, 370 (1962).

25) D.S. McClure, J. Chem. Phys. 36, 2757 (1962).
26) R. Müller, Hs. H Günthard, J. Chem. Phys. 44, 365 (1966).

27) D. Reinen, Z. anorg. allgem. Chem. 327, 238 (1964).

$(10 / 13 / 1967$ 受付 $)$

\title{
$10^{7} \sim 10^{16}$ poise の範囲におけるガラスの 粘度測定に対する beam-bending 法の適用
}

\author{
小 林 啓 二・横 田 良 助 \\ （東京芝浦電気朲式会社中央研究所）
}

\section{Application of Beam-bending Method to Measurement of Glass Viscosity in Range of $10^{7} \sim 10^{16}$ poises}

By

\author{
Keiji KOBAYASHI and Ryosuke YOKOTA
}

(Central Research Laboratory Tokyo Shibaura Electric Co.,Ltd. Kawasaki, Japan)

\begin{abstract}
Beam-bending method that one used to measure the sag point of glass was tried to apply to the viscosity measurement of the relatively unstable glasses. An electrical circuit making connections between the differential transformer and the recording millivoltmeter was newly designed. This enables the viscosity measurement in range of $10^{7} \sim 10^{16}$ poises involving annealing point and sag point. Annealing point of a commercial soda-lime glass measured by this method coincided with that obtained by the fibre-elongation method. Furthermore, results of viscosity measurements of glasses in the systems of $\mathrm{Li}_{2} \mathrm{O}-\mathrm{B}_{2} \mathrm{O}_{3}-$ $\mathrm{SiO}_{2}-\mathrm{Al}_{2} \mathrm{O}_{3}, \mathrm{Li}_{2} \mathrm{O}-\mathrm{Al}_{2} \mathrm{O}_{3}-\mathrm{SiO}_{2}$ and $\mathrm{Na}_{2} \mathrm{O}-\mathrm{Al}_{2} \mathrm{O}_{3}-\mathrm{SiO}_{2}$ were given. The glasses in the two former systems are so apt to crystallize or separate into two phases at a temperature near the sag point that they can hardly be obtained in a form of relatively long fibre as homogeneous state. The present method is especially suited for measuringt he annealing point and sag point of glass in case that the glass to be subjected cannot be got in a large amount because of the preciousness or the experimental situation.

(Received Oct. 16, 1967)
\end{abstract}

\section{1. 緒 言}

ガラスの粘度が $10^{8} \sim 10^{15}$ poise の範围の粘度測定法 としては fibre-elongation 法 $^{1)}$ が現在もっとも広く用い られている、しかしこの測定法は，(1) 自動記録が容易 でない，(2) 繊維状の比較的長いガラスの試料を必要と するので熱加工により変質しがたい安定なガラスでなけ れば適用できないという欠点がある。一方，Trouton ${ }^{21}$ は棒状の試料を 2 点で水平に支持した場合の棒状試料の 自重によるたわみの変形速度と粘度との間の関係式を導 いた. $\mathrm{Hagy}^{3}{ }^{3}$ はこの測定法に改良を加え，ガラス棒の $2 つ の$ 支点間の中央に荷重を加えて，これを炉内で加熱 した場合のたわみ速度と粘度との閒の関係式を出した。 この方法を beam-bending 法という. Hagy は N.B.S. 製標準 No.710 ガラズ)の粘度を測定し, fibre-elongation 法による測定值と一致することを確認した.われわれ は，Hagy の方法を使用すれば（1）と（2）の欠点がなく
なることに着目し，新しく電気回路に工夫を加えて， Hagy の方法よりもさらに広い粘度範囲，すなおち $10^{7}$ $10^{16}$ poise の粘度をひとつの装置で直接に測定できる方 法を開発した.

この方法によれば，試料の寸法，荷重を一定にし，か つ一定速度で加熱していく場合に, 急激に伸びが増加し はじめる粘度に対応する温度を求めることができる。こ れを本方法に拉ける sag point と名ゔけ，われわれはこ れをガラスの粘度の定点としてガラスの製造における品 質管理の目安のひとつとすることを提案する. sag point の測定法には Hirayama ${ }^{5}$ の方法, Spinner ${ }^{6)}$ らの方法 もあるが，すべて自重によるたわみを測定しているので あって完全な粘度測定法といいがたい.これらの方法で も，角棒または繊維状のいずれの形の試料でも測定でき るが，その自動記録はむずかしく，かつ測定できる粘度 の範囲がわれわれの方法よりもせまい. Gott ${ }^{7}$ の beam- 